\title{
Characteristics of solar radiation at Xiaotang, in the northern marginal zone of the Taklimakan Desert
}

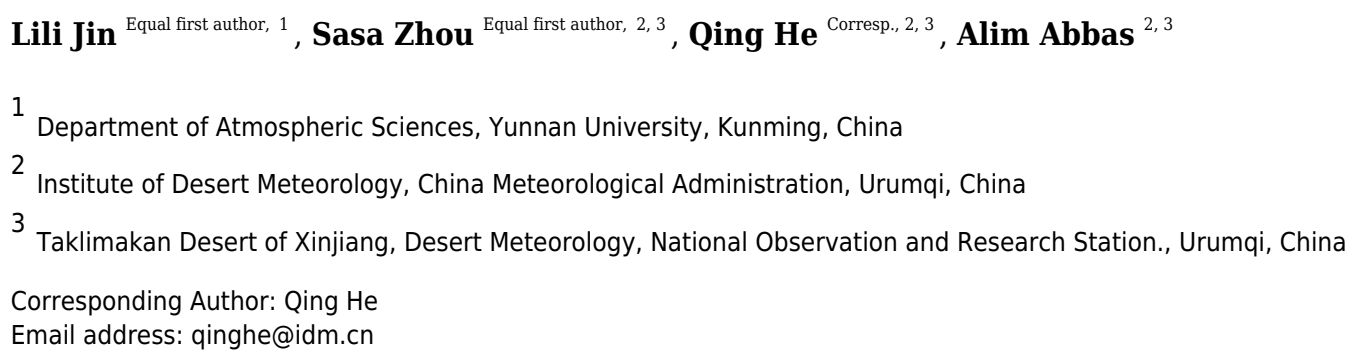

The characteristics of solar radiation and the influence of sand and dust on solar radiation in the northern margin of Taklimakan Desert were analyzed using radiation observation data from 2018. The results showed that the annual total radiation, direct radiation, and scattered radiation at Xiaotang were $5781.8,2337.9$, and $3323.8 \mathrm{MJ} \cdot \mathrm{m}^{-2}$, respectively. The maximum monthly total radiation, direct radiation, and scattered radiation were observed in July $\left(679.8 \mathrm{MJ} \cdot \mathrm{m}^{-2}\right)$, August $\left(317.3 \mathrm{MJ} \cdot \mathrm{m}^{-2}\right)$, and May $\left(455.7 \mathrm{MJ} \cdot \mathrm{m}^{-2}\right)$, respectively. The aerosol optical depth corresponded well with the scattered radiation, and the maximum value was in May. Further analysis showed a significant correlation between the total radiation and solar height angle under different weather conditions. Under the same solar height angle, total radiation was higher during clear days but lower on sandstorm days. Calculation of atmospheric transmittance showed that the average atmospheric transmittance on a clear day was 0.67 ; on sand-and-dust days, it was 0.46 . When the atmospheric transmittance was 0.5 , the increase in scattering radiation by aerosol in the air began to decrease. Probability analysis of radiation indicated the following probabilities of total radiation $<500 \mathrm{~W} \cdot \mathrm{m}^{-2}$ occurring on clear, floating-dust, blowing-sand, and sandstorm days: $67.1 \%, 76.3 \%, 76.1 \%$, and $91.8 \%$, respectively. Dust had the greatest influence on direct radiation; the probabilities of direct radiation $<200 \mathrm{~W} \cdot \mathrm{m}^{-2}$ occurring on clear, floating-dust, blowing-sand, and sandstorm days were $44.5 \%, 93.5 \%, 91.3 \%$, and $100 \%$, respectively, whereas those of scattered radiation $<600 \mathrm{~W} \cdot \mathrm{m}^{-2}$ were $100 \%, 99.1 \%$, $98.1 \%$, and $100 \%$, respectively. Therefore, the presence of dust in the air will reduce scattered radiation. 
1 Manuscript Title

2 Lili Jin ${ }^{\# 1}$, Sasa Zhou ${ }^{\# 2}$, Qing $\mathrm{He}^{* 2,3}$, Alim.Abbas ${ }^{2,3}$

$3{ }^{1}$ Department of Atmospheric Sciences, Yunnan University, Kunming 650500,

4 China.

$5 \quad 2$ Institute of Desert Meteorology, China Meteorological Administration, Urumqi

6830002 , China.

$7{ }^{3}$ Taklimakan Desert of Xinjiang, Desert Meteorology, National Observation and R

8 esearch Station, China.

10 Corresponding Author: Qing He

11 No.327 Jianguo Road, Tianshan District, Urumqi, Xinjiang, China

12 Email address: qinghe@idm.cn 


\section{Characteristics of solar radiation at Xiaotang in the northern marginal zone} of the Taklimakan Desert

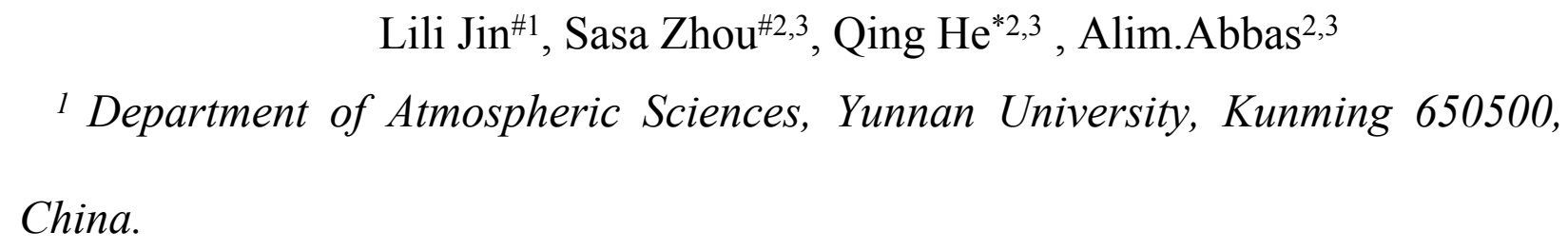

\section{ABSTRACT}

The characteristics of solar radiation and the influence of sand and dust on solar radiation in the northern margin of the Taklimakan Desert were analyzed using radiation observation data from 2018. The results showed that the annual total, direct, and scattered radiations at Xiaotang were 5781.8, 2337.9, and 3323.8 $\mathrm{MJ} \cdot \mathrm{m}^{-2}$, respectively. The maximum monthly total, direct, and scattered radiations were observed in July $\left(679.8 \mathrm{MJ} \cdot \mathrm{m}^{-2}\right)$, August $\left(317.3 \mathrm{MJ} \cdot \mathrm{m}^{-2}\right)$, and May (455.7 $\mathrm{MJ} \cdot \mathrm{m}^{-2}$ ) in 2018 , respectively. The aerosol optical depth corresponded well with the scattered radiation, and the maximum value of the aerosol optical depth (AOD) was in May. Further analysis showed a significant correlation between the total 
33 radiation and solar height angle under different weather conditions. Under the 34 same solar height angle, the total radiation was higher during clear days but lower

35 on sandstorm days. Calculation of atmospheric transmittance showed that the 36 average atmospheric transmittance on a clear day was 0.67 ; on sandy and dusty 37 days, it was 0.46 . When the atmospheric transmittance was $>0.5$, the rate of 38 increase in scattering radiation by aerosols in the air began to reduce. The 39 probability analysis of radiation indicated the following probabilities of the 40 occurrence of the total radiation $<500 \mathrm{~W} \cdot \mathrm{m}^{-2}$ on clear, floating-dust, blowing-sand, 41 and sandstorm days: $67.1 \%, 76.3 \%, 76.1 \%$, and $91.8 \%$, respectively. Dust had the 42 greatest influence on direct radiation; the probabilities of the occurrence of the 43 direct radiation $<200 \mathrm{~W} \cdot \mathrm{m}^{-2}$ on clear, floating-dust, blowing-sand, and sandstorm 44 days were $44.5 \%, 93.5 \%, 91.3 \%$, and $100 \%$ whereas those of scattered radiation $<$ $45600 \mathrm{~W} \cdot \mathrm{m}^{-2}$ were $100 \%, 99.1 \%, 98.1 \%$, and $100 \%$, respectively. Therefore, the 46 presence of dust in the air will reduce the scattered radiation.

47 Subjects Atmospheric science, Radiation science

Desert

\section{INTRODUCTION}

Solar energy is the most fundamental renewable energy source on the earth's

52 surface, and global solar radiation plays an important role in a wide range of

53 applications, such as in the areas of meteorology and hydrology (Almorox et al., 
54 2013). Solar radiation is a primary factor in several applications, such as solar

55 energy systems, architecture, agriculture, and irrigation (Almorox et al., 2004). The

56 solar radiation that reaches the ground is divided into two parts: solar direct

57 radiation and scattered radiation. The former is directly projected onto the ground

58 in the form of parallel rays, and the latter is projected from the sky to the ground

59 after scattering. The sum of these two radiations is called total radiation. The solar

60 radiation reaching the ground is mainly affected by astronomical factors and the

61 earth's atmosphere (Bullrich, 1964).

62 Many studies state that the total surface radiation and direct radiation have

63 been decreasing in most parts of the world in the 20th century, which may be due

64 to the increase in the concentration of suspended particles in the atmosphere

65 (Gilgen et al., 1998; Wild et al., 2005; Wild, 2012). Che et al. (2005) evaluated

66 China's solar radiation data from 1961 to 2000; they found that the total radiation

67 had decreased significantly $\left(4.5 \mathrm{~W} \cdot \mathrm{m}^{-2}\right.$ per decade $)$, but the diffuse fraction had

68 increased (1.73\% per decade), and an increase in aerosol is partly the reason for the

69 decrease in the observed solar radiation.

70 Dust is a common type of aerosol found in deserts (Smirnov et al., 2002;

71 Masmoudi et al., 2003; Oh SN et al., 2003). It is the most important component of

72 aerosols and accounts for approximately one-third of the total amount of naturally

73 generated aerosols worldwide (Miller et al., 2004; Han et al., 2008), which equates

74 to approximately 1000-4000 Tg per annum (Liu et al., 2011; Jemmett-Smith et al., 
75 2015). Dust aerosols can affect weather and global and regional climate change

76 (Huang et al., 2015; Othman et al., 2010; Kang et al., 2011). They also disturb the

77 radiation-energy balance of the earth-atmosphere system and cause severe

78 biological and ecological impacts that affect human health (Othman et al., 2010;

79 Falkowski et al., 1998; Goudie., 2014). Changes in the number and size of dust

80 particles suspended in the air change their optical properties. According to Xin et al.

81 (2003), on dusty days, the direct radiation in the presence of dust aerosols

82 attenuates by $38 \%$ on average. During sandstorms in the Sahara Desert, the direct

83 interaction of dust with radiation causes an additional reduction of $40-80 \mathrm{~W} \cdot \mathrm{m}^{-2}$ in

84 the incoming shortwave radiation. The strong radiative force associated with dust

85 causes a reduction in the surface temperature in the order of -0.2 to $-0.5 \mathrm{~K}$ in most

86 parts of France, Germany, and Italy during dust events (Bangert et al., 2012;

87 Slingo et al., 2006). The use of radiation models to simulate radiative fluxes underestimates the observed absorption of solar radiation in dusty atmospheres

89 (Davidi et al., 2012). The dust in the atmosphere greatly disturbs the total radiation

90 balance of the underlying surface while inducing general warming of the

91 underlying surface-atmosphere system owing to a decrease in the system albedo

92 over arid zones (Sokolik et al., 1993). Mani et al. (1980) discussed the contribution

93 of dust to the attenuation of solar radiation in the Rajasthan Desert by the

94 scattering and absorption of radiation. In summer, the dust aerosols attenuate solar

95 radiation by up to $40 \%$. Using MODIS satellite observation data, Hatzianastassiou 
96

97 absorb $15-55 \mathrm{~W} \cdot \mathrm{m}^{-2}$ of incident solar radiation, with the maximum absorption

et al. (2014) found that aerosols in the desert regions of Asia and Africa strongly occurring in the Sahara.

In China, strong sand and dust events mainly occur in the Taklimakan Desert and the eastern and northern parts of northern China (Zhou et al., 2002). Previous studies on radiation in the hinterland of the Taklimakan Desert have examined the impact of sand and dust on radiation (Meng et al., 2019; Ye et al., 2015); however, there are limited studies on the impact of sand and dust on radiation in the margin of the Taklimakan Desert. Huang et al. (2010) attempted to improve the accuracy of the simulation analysis of clear-sky surface shortwave radiation using the CERES SSF dataset, and aerosol optical depth (AOD) plays a crucial role in deciding the accuracy of simulation analysis. Jin et al. (2011) conducted UAV experiments and found that particles size, concentrations, and daily variations in the concentration of PM were different in the Xiaotang and Tazhong Station. On clean days, the mean concentrations of $\mathrm{PM}_{1.0}, \mathrm{PM}_{2.5}$, and $\mathrm{PM}_{10}$ were 3.6, 6.9, and $18.9 \mu \mathrm{g} \cdot \mathrm{m}^{-3}$ in the Xiaotang area and $6.5,13.2$, and $26.8 \mu \mathrm{g} \cdot \mathrm{m}^{-3}$ in the Tazhong area, respectively. There are differences in natural environment and altitude between the hinterland and the margin of Taklimakan Desert. Using radiation observation data from the Xiaotang land-atmosphere interaction observatory and experiment station $\left(40.8^{\circ} \mathrm{N}, 84.3^{\circ} \mathrm{E}\right)$, we can further understand the characteristics of radiation changes in the desert margin area during the dust weather in 2018. The findings 
117 will be of great significance for understanding climate change and ecological 118 protection in the arid region of northwestern China, and they will provide basic 119 data for studying the radiation balance of oasis-desert transition zones and the 120 effects of dust aerosols on radiation.

\section{OVERVIEW OF STUDY AREA, DATA, AND METHODS}

122

123

124

125

126

127

128

129

130

131

132

133

134 135

\section{Study area}

Xiaotang is located at the northern margin of the Taklimakan Desert, northwestern China (Fig. 1). This area lies in the desert-oasis transition zone on the northern margin of the Taklimakan Desert. The underlying surface is a relatively flat, bare, wind-eroded ancient riverbed. It has a warm temperate desert climate that is extremely arid and has a high potential for evaporation. The annual average temperature, precipitation, and wind speed are $10^{\circ} \mathrm{C}, 15.2 \mathrm{~mm}$, and $2.5 \mathrm{~m} \cdot \mathrm{s}^{-1}$, respectively. The frequency of sandy and dusty weather is extremely high. Sandstorms and dusty devils occur in all seasons. Surface soils mainly comprise fine sand $(125-250 \mu \mathrm{m})$ and very fine sand $(62.5-125 \mu \mathrm{m})($ Ma et al., 2010).

The observation site is in the northern margin of Taklimakan Desert. The Xiaotang land-air interaction observatory station $\left(40.8^{\circ} \mathrm{N}, 84.3^{\circ} \mathrm{E}\right.$; altitude $=932$ $\mathrm{m})$ is on the south bank of the ancient riverbed, $\sim 2 \mathrm{~km}$ north of a Populus euphratica forest that is minimally affected by human activities. According to the 
136 meteorological data from the Xiaotang observatory station, the average

137 temperature of the northern margin of Taklimakan Desert in 2018 was $11.3^{\circ} \mathrm{C}$, the

138 highest temperature was $39.4^{\circ} \mathrm{C}$ (in summer), and the lowest temperature was -40 .

$13911^{\circ} \mathrm{C}$ (in winter) (Fig. 2). In 2018, the annual average wind speed was $1.6 \mathrm{~m}^{\cdot} \mathrm{s}^{-1}$, and

140 the annual relative humidity was $34.95 \%$.

141 Observation instrument

142

143

144

145

146

147

148

149

150

151

152

153

154

155

156

The Xiaotang land-atmosphere interaction observatory and experiment station used internationally recognized radiation detection sensors (Table 1). The measured parameters included total, direct, and scattered radiations. The model of A CR3000 micrologger (Campbell, United States) was used as the radiation data collector. The acquisition frequency was $1 \mathrm{~s}$, and the output data were obtained at 1 $\mathrm{s}, 1 \mathrm{~min}, 30 \mathrm{~min}$, and $1 \mathrm{~h}$. In this paper, we used hourly data for our analysis. The clock of the collector adopted the local real solar time, which later Beijing time by 2 h $22 \min 48 \mathrm{~s}$.

According to the specifications, the radiometer was inspected and maintained every day, and the radiometer was wiped before sunrise. Some false data appeared due to instrument system errors, instrument failure, etc. during data transmission and recording. The following data must be corrected or eliminated: the output flux value is NAN.

\section{Data and methods}

The satellite data were obtained from the CERES_SYN1deg_Ed4A daily 
157 product data provided by the Atmospheric Science Data Center at NASA Langley

158 Research Center. The accuracy of the CERES sensor for the atmospheric AOD

159 measurements was $1^{\circ}$. Aerosol optical thicknesses were obtained using an aerosol

160 transport model MATCH (Collins et al. 2001) that assimilated and spatially as well

161 as temporally interpolated MODIS aerosol optical thickness. Additionally,

162 MATCH provided aerosol types. The atmospheric AOD data were downloaded

163 from the following link: http://ceres.larc.nasa.gov/.

164 The total, direct, scattered radiations' data and ground meteorological 165 observation data from the Xiaotang land-atmosphere interaction observatory and 166 experiment station from January 1, 2018 to December 31, 2018 were used in this 167 study. In this study, the months of March-May, June-August, September168 November, and December-February are considered as spring, summer, autumn, 169 and winter, respectively.

170 Kipp \& Zonen's A2P automatic tracker direct radiation meter was used to 171 measure the direct solar radiation on the vertical plane; however, the direct solar 172 radiation on the horizontal plane was required to analyze the direct radiation. 173 Therefore, the direct radiation measured by the instrument was converted using the 174 following formula (Mamtimin et al., 2007):

$$
R_{b}=R_{b}^{\prime} \sinh ,(1)
$$

176 where $R_{b}$ is the direct horizontal radiation, $R_{b}{ }^{\prime}$ is the direct normal radiation, and $h$ 177 is the solar height angle. 
In Eq. (1), the solar height angle was calculated using the following equation:

$$
\sinh =\sin \varphi \sin \delta+\cos \varphi \cos \delta \cos \mathrm{t}, \text { (2) }
$$

180 where $\varphi$ (radian) is the local latitude, $\delta$ (radian) is the solar declination, and $t$ is the 181 hour angle.

182 The ratio of total radiation to total astronomical radiation is equivalent to the 183 transmittance of the whole atmosphere. This parameter is called atmospheric 184 transmittance in this paper (Tian et al., 2018).

185 The atmospheric transparency coefficient is an essential parameter for 186 characterizing the degree of atmospheric turbidity. Therefore, the variation of the 187 atmospheric transparency coefficient was used to discuss the influence of dust 188 aerosols on direct solar radiation. The atmospheric transparency coefficient was 189 calculated according to Equations (3) and (4).

$$
s=s_{0} p^{m}
$$

191

$$
p=\left(\frac{s}{s_{0}}\right)^{1 / m} \text {, }
$$

192 where $S$ is direct radiation, $\mathrm{S}_{0}$ is the solar constant, and $m$ is the atmospheric mass.

193 We obtained the value of $S$ when $m=2$, and calculated $P_{2}$ according to Equation 194 (5). 


$$
p_{2}=\left[\frac{m / 2 p^{m}}{1-\left(\frac{1}{2} m\right) p^{m}}\right] \text {, }
$$

where $P_{2}$ is the atmospheric transparency when the relative atmospheric mass is corrected to be 2 (that is, the solar altitude angle $=90^{\circ}$ ).

The characteristics of total, direct, and scattered radiations at Xiaotang during different seasons and sandy and dusty weathers were analyzed. Five typical days were selected for each clear, floating-dust, blowing-sand, and sandstorm weathers from spring to summer, when sandy and dusty days were more frequent. However, owing to limitations in the weather phenomena, four sunny days were selected for spring and summer and two floating-dust days were selected for summer. The daily changes in the sand and dust at Xiaotang were analyzed. Because dusty weather at Xiaotang was mainly observed during spring and summer, autumn and winter were not analyzed here.

A total cloudiness of $<20 \%$ and no weather phenomenon indicated a clear day. When the dust and fine sand floated evenly in the air such that the horizontal visibility was $<10 \mathrm{~km}$, indicated a floating-dust day. Blowing-sand and sandstorm indicated the weather phenomenon in which the wind lifts the dust from the ground, making the horizontal visibility in the range of $1-10 \mathrm{~km}$ and less than $1 \mathrm{~km}$, respectively.

In spring, the selected clear days were March 1, April 25, April 30, and May 
214 12; the floating-dust days were March 6, March 7, March 9, March 16, and March

215 20; the blowing-sand days were March 17, March 29, April 5, April 12, and April

216 19; and the sandstorm days were March 3, March 19, April 2, April 11, and May

217 11. Their averages under these different weather conditions were then calculated.

218 In summer, the selected typical clear days were June 19, July 22, July 23, and

219 August 21; the floating-dust days were June 1 and 2; the blowing-sand days were

220 June 5, June 15, June 28, July 16, and July 24; and the sandstorm days were June

221 16, June 30, July 15, August 23, and August 29. Then, their averages were 222 calculated under these different weather conditions.

\section{RESULTS AND DISCUSSION}

224

225

226

227

228

229

230

231

232

Monthly variation of total, direct, and scattered radiations

In 2018, the total, direct, and scattered radiations at Xiaotang show fluctuating distributions with an evident seasonality (Fig. 3). The annual total, direct, and scattered radiations are $5781.8,2337.9$, and $3323.8 \mathrm{MJ} \cdot \mathrm{m}^{-2}$, respectively. The total annual radiation at the Xiaotang area $\left(5781.8 \mathrm{MJ} \cdot \mathrm{m}^{-2}\right)$ is lower than that at the Tazhong Station $\left(6515 \mathrm{MJ} \cdot \mathrm{m}^{-2}\right)$, which is in the hinterland of the Taklimakan Desert.

Figure 4 shows that the maximum monthly total radiation concentration occurs from June to August and the total radiation peaks in July $\left(679.8 \mathrm{MJ} \cdot \mathrm{m}^{-2}\right)$, 
233 accounting for $11.7 \%$ of the total radiation for the whole year.

234 The total annual direct radiation is $2337.9 \mathrm{MJ} \cdot \mathrm{m}^{-2}$, accounting for $42.4 \%$ of 235 the annual total radiation. The peak value of the monthly total amount is seen in 236 August (317.3 $\left.\mathrm{MJ} \cdot \mathrm{m}^{-2}\right)$, accounting for $\sim 12.6 \%$ of the total annual direct radiation, 237 and it reaches the lowest value $\left(102.1 \mathrm{MJ} \cdot \mathrm{m}^{-2}\right)$ in December (winter).

238 The scattered radiation begins to rise in January $\left(138.1 \mathrm{MJ} \cdot \mathrm{m}^{-2}\right)$ and reaches 239 the peak value $\left(455.7 \mathrm{MJ} \cdot \mathrm{m}^{-2}\right)$ in May, which accounts for $13.7 \%$ of the total 240 annual scattered radiation. Under high solar height angles observed in June, July, 241 and August, the scattered radiation is $396.4,353.4$, and $314.9 \mathrm{MJ} \cdot \mathrm{m}^{-2}$, respectively. 242 The total, direct, and scattered radiations reach the lowest levels in December, with 243 monthly totals of $242.4,102.1$, and $133.6 \mathrm{MJ} \cdot \mathrm{m}^{-2}$, respectively.

244 Figure 5 shows that high daily variations of solar radiation reflect frequent 245 changes in weather conditions and synoptic events. The amount of total radiation 246 gradually increases from spring, and the peak value is reached in summer (1967.8 $247 \mathrm{MJ} \cdot \mathrm{m}^{-2}$ ), which accounts for $34.03 \%$ of the annual total radiation; the values are 248 mainly concentrated between 15 and $30 \mathrm{MJ} \cdot \mathrm{m}^{-2}$. It reaches the lowest value in 249 winter $\left(862.9 \mathrm{MJ} \cdot \mathrm{m}^{-2}\right)$. The values in December are mainly concentrated between 2507 and $9 \mathrm{MJ} \cdot \mathrm{m}^{-2}$ for 23 days, and the values in January-February are mainly 251 concentrated between 9 and $12 \mathrm{MJ} \cdot \mathrm{m}^{-2}$ for 31 days. The amount of total radiation 252 follows an order of summer $>$ spring $>$ autumn $>$ winter. 
254 amount of direct radiation in summer is $864.4 \mathrm{MJ} \cdot \mathrm{m}^{-2}$, accounting for $35.3 \%$ of the 255 total annual direct radiation. The amounts in spring and summer are mainly 256 concentrated between 0 and $15 \mathrm{MJ} \cdot \mathrm{m}^{-2}$, with large fluctuations and lasting for 164 257 days. The value gradually decreases in autumn. In winter, the amount of direct 258 radiation reaches the lowest value of $364.3 \mathrm{MJ} \cdot \mathrm{m}^{-2}$, with the magnitude mainly 259 concentrated between 2 and $5 \mathrm{MJ} \cdot \mathrm{m}^{-2}$ for 54 days. The amount of direct radiation 260 follows an order of summer $>$ autumn $>$ spring $>$ winter.

261 During the year, the amount of scattered radiation reaches the maximum value 262 in spring $\left(1182.4 \mathrm{MJ} \cdot \mathrm{m}^{-2}\right)$. The amount of scattered radiation in summer is 1064.7 $263 \mathrm{MJ} \cdot \mathrm{m}^{-2}$, and the total amount in spring and summer accounts for $67.61 \%$ of the 264 total scattered radiation in the year. The amounts of scattered radiation in the two 265 seasons are mainly concentrated between 8 and $18 \mathrm{MJ} \cdot \mathrm{m}^{-2}$, with great fluctuations 266 and lasting for 158 days. In spring and summer, the scattered radiation lasts for 141 267 days longer than the direct radiation. The scattering radiation in autumn is 619.1 $268 \mathrm{MJ} \cdot \mathrm{m}^{-2}$, and the value gradually decreases. The lowest value of scattered radiation 269 is $457.7 \mathrm{MJ} \cdot \mathrm{m}^{-2}$ (winter), accounting for $13.8 \%$ of the annual total amount of 270 scattered radiation. The value of scattered radiation is mainly concentrated between 2713 and $6 \mathrm{MJ} \cdot \mathrm{m}^{-2}$ and lasts for 80 days in December. The amount of scattered 272 radiation follows an order of spring $>$ summer $>$ autumn $>$ winter.

Relationship between solar radiation and solar height angle 
275 height angle under different weather conditions (Fig. 6). The square values of the 276 correlation coefficients are 0.97 and 0.81 for clear and sandstorm days, 277 respectively. In sandstorm weather, the total radiation slowly increases with the 278 increase in the solar height angle, mainly due to the increase in dust content in the 279 air. When the solar height angle is $10^{\circ}$, the total radiation amounts in clear, 280 floating-dust, blowing-sand, and sandstorm days are 118.6, 19.7, 10.4, and 4.0 $281 \mathrm{~W} \cdot \mathrm{m}^{-2}$, respectively. The higher the solar height angle, the more the radiation 282 received by the ground. However, at the same solar height angle, the total radiation 283 is the highest on clear days, while the total radiation in sandstorm weather is the 284 lowest (Fig. 6). Solar radiation is affected by the solar height angle, atmospheric 285 conditions, latitude, water vapor, cloud cover, and other factors. Here, this is 286 mainly the influence of atmospheric conditions on solar radiation.

287 Characteristics of atmospheric transmittance

288 In total, $55.9 \%$ of astronomical radiation enters the ground, and the annual 289 variation range is mainly between $30 \%$ and $74 \%$. On clear days, the total radiation 290 reaching the ground is $68.1 \%$, with a variation range of $60 \%-70 \%$. The total 291 radiation reaching the ground on dusty days is $47.6 \%$, with a variation range of $29230 \%-60 \%$. The variation range on clear days is mainly concentrated between $60 \%$ 293 and $70 \%$ and that on the sandy and dusty days is mainly concentrated between $29430 \%$ and $60 \%$. The annual average atmospheric transmittances on clear, floating295 dust, blowing-sand, and sandstorm days at the Xiaotang area are 0.67, 0.46, 0.44, 
296 and 0.30, respectively. Many studies show that the particle-size distribution, 297 vertical distribution, and mineral composition of dust have important effects on 298 radiation (Tegen, 1994; Sokoliket al., 1993;1996).

As seen in Fig. 7, atmospheric conditions affect the total and scattered 300 radiations. The higher the atmospheric transmittance, the weaker the scattered 301 radiation and the smaller the ratio of the scattered radiation to the total radiation $302\left(R_{d} / R_{s}\right)($ Fig. $7(\mathrm{~A}))$. By contrast, as the atmospheric transmittance decreases, the 303 scattered radiation and $R_{d} / R_{s}$ increase. The ratio of the scattering radiation to the 304 astronomical radiation $\left(R_{d} / Q_{d}\right)$ indicates the contribution of the atmosphere to 305 scattered radiation (relative to astronomical radiation). (Fig. 7(B)). However, when 306 the atmospheric transmittance is larger than $0.5, R_{d} / Q_{d}$ begins to decrease. Diurnal variation of radiation on dusty day in spring and summer

Figure 8 shows that the distributions of hourly total, direct, and scattered 309 radiations are normal during midday on clear days. The amount of radiation 310 increases from sunrise and reaches the maximum value at 12:00 LST or 13:00 LST 311 in spring and summer. By contrast, the distribution becomes irregular owing to the 312 reduction in total radiation and direct radiation associated with dust aerosols. The 313 value of direct radiation decreases at the Xiaotang Station. In spring (Fig. 8(A)), 314 the daily peaks of total, direct, and scattered radiations on clear days are 862.4, 315504.5 , and $339.6 \mathrm{~W} \cdot \mathrm{m}^{-2}$, while in summer (Fig. 8(B)), the daily peaks are 915.8 , 316643.4 , and $253.5 \mathrm{~W} \cdot \mathrm{m}^{-2}$, respectively. 
In spring (Fig. 8(A)), compared with the radiation values on clear days, the

318 daily total values of total radiation decrease by $41.7 \%, 43.8 \%$, and $62.8 \%$; those of

319 direct radiation decrease by $89.6 \%, 88.0 \%$, and $97.6 \%$; and the total daily values of

320 scattered radiation increase by $9.1 \%, 6.4 \%$, and $4.9 \%$ in floating-dust, blowing321 sand, and sandstorm days, respectively.

Figure 8(A) shows that the daily variation curves of total and scattered radiations on blowing-sand and sandstorm days are similar, and the magnitudes are close. In summer (Fig. 8(B)), compared with the radiation values on clear days, the daily total values of total radiation decrease by $18.5 \%, 26.9 \%$, and $57.5 \%$, in floating-dust, blowing-sand, and sandstorm days, respectively. Those of direct radiation decrease by $81.5 \%, 76.4 \%$, and $89.3 \%$; and the total daily values of scattered radiation increase by $52.2 \%, 51.1 \%$, and $9.2 \%$ in floating-dust, blowingsand, and sandstorm days, respectively. In general, the impact of sand and dust on radiation at the Xiaotang area is greater in spring than that in summer. According to the ground observation records

332 (Table 2), the rainfall at the Xiaotang area is mainly concentrated in summer, with 333 a total of 37 days. The occurrence of sandstorms is often accompanied by rainfall, 334 which reduces the dust content in the air. In summer, there are nine sandstorms, 335 five of which are accompanied by rainfall. In spring, there are more dusty days and 336 less rainfall. Wang et al. (2001) calculated the sand transport rate formula fitted 337 using field-measured data and found that the annual sediment transport in the 
338 Xiaotang area was $3800 \mathrm{~kg} \cdot \mathrm{m}^{-1}$, which is higher than the annual sediment transport

339 in some oases on the edge of Tarim (Yang et al., 2012), and the direction of sand

340 transport was relatively scattered in the Xiaotang area. The underlying soil

341 comprises fine $(125-250 \mu \mathrm{m})$ and very fine $(62.5-125 \mu \mathrm{m})$ sand. The smaller the

342 particle size, the stronger the scattering effect on light and the larger the scattering 343 angle.

344 Probability distribution characteristics of total, direct, and scattered radiations in 345 different dust weathers

346 The total, direct, and scattered radiations at the Xiaotang area differed under 347 the various weather conditions. Therefore, the distribution law was further 348 analyzed, and the total, direct, and scattered radiations on clear, floating-dust, 349 blowing-sand, and sandstorm days at the Xiaotang area were statistically examined. 350 The probability distribution of the radiations is shown in Fig. 9.

351 The total radiation can reach $900-100 \mathrm{~W} \cdot \mathrm{m}^{-2}$ in clear, floating-dust, and 352 blowing-sand weather, while the value varies between 700 and $800 \mathrm{~W} \cdot \mathrm{m}^{-2}$ on 353 sandstorm days. In sandstorm weather, the probability of total radiation $>600$ $354 \mathrm{~W} \cdot \mathrm{m}^{-2}$ is only $2.2 \%$. On clear, floating-dust, blowing-sand, and sandstorm days, 355 the magnitude in high-value of total radiation areas gradually decreases, gradually 356 concentrating in low-value of total radiation areas. The weakening of total 357 radiation by dust is mainly concentrated in high-value of total radiation areas. 358 The maximum value of direct radiation varies from 800 to $900 \mathrm{~W} \cdot \mathrm{m}^{-2}$ on 
359 clear days, while the value varies between 100 and $200 \mathrm{~W} \cdot \mathrm{m}^{-2}$ in sandstorm days.

360 The probabilities of the occurrence of direct radiation $<500 \mathrm{~W} \cdot \mathrm{m}^{-2}$ are $89.6 \%$,

$361100 \%, 99.4 \%$, and $100 \%$ on clear, floating-dust, blowing-sand, and sandstorm days,

362 respectively. Compared with total radiation, sand and dust have a stronger

363 weakening effect on direct radiation; especially in sandstorm weather, the

364 magnitude is below $200 \mathrm{~W} \cdot \mathrm{m}^{-2}$. The probabilities of occurrence of direct radiation

$365<200 \mathrm{~W} \cdot \mathrm{m}^{-2}$ are $44.5 \%, 93.5 \%, 91.3 \%$, and $100 \%$ in clear, floating-dust, blowing-

366 sand, and sandstorm days, respectively.

367 On clear days, scattered radiation is mainly concentrated between 1 and 300

$368 \mathrm{~W} \cdot \mathrm{m}^{-2}$. In sandy and dusty weather, the maximum scattered radiation can exceed

$369600 \mathrm{~W} \cdot \mathrm{m}^{-2}$. The probabilities of scattered radiation $<300 \mathrm{~W} \cdot \mathrm{m}^{-2}$ occurring on

370 clear, floating-dust, blowing-sand, and sandstorm days are $94.2 \%, 62.5 \%, 61.1 \%$,

371 and $72.1 \%$ and those for the occurrence of scattered radiation $<600 \mathrm{~W} \cdot \mathrm{m}^{-2}$ are

$372100 \%, 99.1 \%, 98.1 \%$, and $100 \%$, respectively. Therefore, as the content of sand

373 and dust in the air increases within a certain range, scattered radiation can be

374 enhanced, especially in floating-dust and blowing-sand weather.

375 Characteristics of atmospheric transparency coefficient

376 The average $P_{2}$ values on clear, floating-dust, blowing-sand, and sandstorm

377 days at the Xiaotang area are $0.57,0.34,0.17$, and 0.08 , respectively. The total,

378 direct, and scattered radiations are closely related to $P_{2}$ (Fig. 10). $\mathrm{P}_{2}$ has a positive

379 correlation with the ratio of the direct radiation to the total radiation $\left(R_{b} / R_{s}\right)\left(\mathrm{R}^{2}=\right.$ 
3800.78 ) (Fig. 10(A)). $R_{b} / R_{s}$ increases with an increase in $P_{2}$, showing an asymmetrical 381 relationship. When $P_{2}=0, R_{b} / R_{s}$ tends to $0 . P_{2}$ is inversely correlated with $R_{d} / R_{s}\left(\mathrm{R}^{2}\right.$ $382=0.49)\left(\right.$ Fig. 10(B)); $R_{d} / R_{s}$ decreases with an increase in $P_{2}$. When $P_{2}=0, R_{d} / R_{s}$ 383 tends to 1 .

384 Direct radiation, scattered radiation, and AOD

385 Figure 11 displays the temporal changes in direct radiation, scattered radiation, 386 and AOD in 2018. The figure shows that the annual variation of AOD is almost the 387 same as that of scattered radiation, reaching the maximum in spring, May (0.71). 388 The two variations have a good consistency. AOD is negatively correlated with 389 direct radiation; there is an evident positive correlation between AOD and scattered 390 radiation, while AOD is the most influencing and important factor for scattered 391 radiation at the Xiaotang area (Huang et al., 2020). AOD is negatively correlated 392 with direct and scattered radiations. Because the Xiaotang area is in the northern 393 margin of Taklimakan Desert, the main aerosol in the air is dust, which leads to the 394 enhancement of scattered radiation.

\section{DISCUSSION}

Analysis of the radiation data of the Xiaotang area in the northern margin of the Taklimakan Desert revealed that the radiation in this area was significantly different from that at the Hade Station (Taklimakan Desert) (Jin et al., 2014), 
399 Tazhong Station (Taklimakan Desert hinterland) (Mamtimin et al., 2014), other 400 desert sites (Yang et al., 2018; Gao et al., 2020), high-latitude areas (Qiao et al., 401 2008; Zhang et al., 2015; Zhang et al., 2013), and other areas (Qiao et al., 2011; 402 Qiu et al., 1996).

403 The annual total radiation was $5781.8 \mathrm{MJ} \cdot \mathrm{m}^{-2}$ at the Xiaotang area in 2018. 404 The annual total radiation was $6515.0 \mathrm{MJ} \cdot \mathrm{m}^{-2}$ at the Tazhong Station during 2007405 2011. The annual total radiation was $5774.5 \mathrm{MJ} \cdot \mathrm{m}^{-2}$ at the Hade Station in 2011. 406 The annual total radiation was $6191.19 \mathrm{MJ} \cdot \mathrm{m}^{-2}$ at the Kelameili Station 407 (Gurbantünggüt Desert) in 2017. The annual total radiation was $4635.0 \mathrm{MJ} \cdot \mathrm{m}^{-2}$ at 408 the Heihe River Basin The annual total radiation was $5988 \mathrm{MJ} \cdot \mathrm{m}^{-2}$ at Hexi corridor. 409 The total annual radiation was $>6000 \mathrm{MJ} \cdot \mathrm{m}^{-2}$ at the Golmud area during $1993-$ 4102011.

411 The annual total amount of direct radiation was $2337.9 \mathrm{MJ} \cdot \mathrm{m}^{-2}$ at the 412 Xiaotang area in 2018. The annual total amount of direct radiation was 2203.5 $413 \mathrm{MJ} \cdot \mathrm{m}^{-2}$ at the Tazhong Station during 2007-2011; The annual total amount of 414 direct radiation was $2772.6 \mathrm{MJ} \cdot \mathrm{m}^{-2}$ at the Heihe River Basin.

415 The annual total amount of scattered radiation was $3323.8 \mathrm{MJ} \cdot \mathrm{m}^{-2}$ at the 416 Xiaotang area in 2018. The annual total amount of scattered radiation was 3628.5 $417 \mathrm{MJ} \cdot \mathrm{m}^{-2}$ at the Tazhong Station during 2007-2011. The annual total amount of 418 scattered radiation was $1682.6 \mathrm{MJ} \cdot \mathrm{m}^{-2}$ at Heihe River Basin.

419 The main reason for this difference is that the Xiaotang area lies in the desert- 
420 oasis transition zone in the northern margin of the Taklimakan Desert. The sandy

421 and dusty days are as many as 30 in spring and summer. Sand and dust are easily

422 brought into the air owing to the lack of vegetation blockage. As the sand-dust

423 content in the air increases and the transparency of the atmosphere decreases, the

424 radiation received by the ground decreases. Precipitation, which plays a major role

425 in eliminating sand and dust from the summer air, is mainly concentrated in

426 summer in the Xiaotang area. The maximum monthly values of total radiation at

427 the Hade Station and Xiaotang area are close; there are little differences in latitude,

428 altitude, and natural environment between these two places.

429 Tazhong Station has a lower geographical latitude $\left(38^{\circ} 58^{\prime} \mathrm{N}, 83^{\circ} 39^{\prime} \mathrm{E}\right.$; altitude

$430=1090 \mathrm{~m}$ ) than the other desert stations (Hade, Xiaotang, Kelameili, and Guaizihu

431 Station). Influenced by the solar altitude angle, the radiation received by the

432 ground at the Tazhong Station is greater the other desert stations. As a mobile

433 desert, the Taklimakan Desert has more sandy and dusty days in spring and

434 summer. In addition, the main particle sizes comprise those of dust, sand, and fine

435 sand $(62.5-125 \mu m)$; they are light and stay in the air for a long time.

436 Gurbantünggüt Desert is a fixed and semi-fixed desert with a high latitude and

437 low altitude $\left(45^{\circ} 14^{\prime} \mathrm{N}, 87^{\circ} 35^{\prime} \mathrm{E}\right.$; altitude $\left.=531 \mathrm{~m}\right)$; its annual total radiation amount

438 is larger than those at the Xiaotang and Hade Stations, which have low latitudes.

439 The main reason is that in spring and summer, Kelameili Station plays a key role in

440 fixing sand on the soil surface layer owing to the vigorous growth of vegetation 
441 and the soil at the observation point has a certain water storage capacity; thus, 442 sand-dust weather cannot easily occur, and sandy and dusty days are few (Gao et 443 al., 2020).

444 In the Guaizihu Station $\left(41^{\circ} 22^{\prime} \mathrm{N}, 102^{\circ} 22^{\prime} \mathrm{E}\right.$; altitude $\left.=960 \mathrm{~m}\right)$, as shown by 445 statistics of weather phenomena, the number of dusty days in spring and summer is 446 considerably smaller than that at the Tazhong Station(Yang et al., 2018).

447 The stations in the Qinghai-Tibet Plateau and Golmud area have higher 448 altitudes (3250 and $2807.6 \mathrm{~m}$ ) and less scattered radiation. When solar rays reach 449 the ground, they pass through a thin atmosphere and the scattering effect is weak. 450 The maximum scattering radiation in the Qinghai-Tibet Plateau, Golmud area, and 451 Xiaotang area occurs in spring, mainly because June-September is the rainfall 452 season in the three areas. Vegetation grows and propagates in this season, and the 453 relative humidity of the air is high; thus, the value of scattering radiation is higher 454 than the value of direct radiation in spring (Zhang et al., 2015).

\section{CONCLUSION}

(1) In 2018, the Xiaotang area's total, direct, and scattered radiations showed fluctuating distributions $\left(5781.8,2337.9\right.$, and $3323.8 \mathrm{MJ} \cdot \mathrm{m}^{-2}$, respectively). The total and direct radiations reached peak values in July $\left(679.8\right.$ and $310.0 \mathrm{MJ} \cdot \mathrm{m}^{-2}$, respectively). The total amount of direct radiation was highest in August (317.3 
$460 \mathrm{MJ} \cdot \mathrm{m}^{-2}$ ); the total amount of scattered radiation reached the peak value in May $461\left(455.7 \mathrm{MJ} \cdot \mathrm{m}^{-2}\right)$. The three factors, i.e., total, direct, and scattered radiations, were 462 observed to be the lowest in December.

(2) In 2018, the Xiaotang area's total, direct, and scattered radiations showed 464 an evident seasonality. There were many windy and sandy days in spring and 465 summer; as the content of sand and dust in the air increased, the scattered radiation 466 increased, with the highest value occurring in spring. Summer rainfall played a role 467 in cleaning the air; consequently, the atmospheric transparency increased and the 468 total and direct radiations became the largest in summer. Therefore, the weakening 469 of the effect of dust on radiation at the Xiaotang area was greater in spring than 470 that in summer. In winter, the solar altitude angle and total, direct, and scattered 471 radiations were the lowest.

(3) The annual average atmospheric transmittances on clear and dusty days at the Xiaotang area were 0.67 and 0.46 , respectively. Dust had the greatest influence 474 on direct radiation, making it concentrate in low-value areas $\left(1-200 \mathrm{~W} \cdot \mathrm{m}^{-2}\right)$. The 475 probability of total radiation $<200 \mathrm{~W} \cdot \mathrm{m}^{-2}$ occurring in sandstorm weather was 476 $100 \%$. Sand and dust can enhance the scattering radiation in a certain range; if the 477 sand and dust content in the air is too high (atmospheric transmittance was larger 478 than 0.5$)$, the scattering radiation will be weakened.

(4) Total, direct, and scattered radiations are closely related to $P_{2}$. At the 
481 September-December. On clear, floating-dust, blowing-sand, and sandstorm days, $482 P_{2}$ values were $0.57,0.34,0.17$, and 0.08 , respectively.

\section{ACKNOWLEDGMENTS}

The authors would like to thank the Institute of Desert Meteorology, China

485

486

487

488

489

490

491

492

493

494

495

496

497

498

499

500

501

Almorox J, Bocco M, Willington E. 2013. Estimation of daily global solar radiation from measured temperatures at Cañada de Luque, Córdoba, Argentina. Renewable Energy, 60, 382-387. DOI: 10.1016/j.renene.2013.05.033

Almorox J, Hontoria C. 2004. Global solar radiation estimation using sunshine duration in Spain. Energy Conversion and Management, 45(9-10), 1529-1535. DOI: 10.1016/j.enconman.2003.08.022.

Bullrich K. 1964. Scattered radiation in the atmosphere and the natural aerosol. Advances in Geophysics, 10(296), 99-260. DOI: 10.1016/S00652687(08)60007-2.

Gilgen H, Wild M, Ohmura A. 1998. Means and trends of shortwave irradiance at the surface estimated from global energy balance archive data. Journal of Climate, 11(8), 2042-2061. DOI: 10.1175/1520-0442-11.8.2042. 
502

Wild M, Gilgen H, Roesch A, Ohmura A, Long CN, Dutton EG, Forgan B, Kallis A, Russak V, Tsvetkov A. 2005. From dimming to brightening: decadal changes in solar radiation at earth's surface. Science, 308(5723), 847850.

Wild M. 2012. Enlightening global dimming and brightening. Bulletin of the American Meteorological Society, 93(1), 27-37. DOI: 10.1175/BAMS-D-1100074.1.

Che H, Shi G, Zhang X, Arimoto R, Zhao J, Xu L, Wang B, Chen Z. 2005. Analysis of 40 years of solar radiation data from china, 19612000. Geophysical Research Letters., 32(6), 2341-2352. DOI: 10.1029/2004GL022322

Smirnov A, Holben BN, Dubovik O, Dubovik Ol, O'"Neill, NT., Eck TF, Westphal DL, Goroch AK, Pietras, C. 2002. Atmospheric aerosol optical properties in the Persian gulf. Journal of the Atmospheric Sciences, 59(3), 620634. DOI: 10.1175/1520-0469(2002)0592.0.CO;2

Masmoudi M, Chaabane M, Tanré D, Gouloup P, Blarel L, Elleuch F. 2003. Spatial and temporal variability of aerosol: size distribution and optical properties. Atmospheric Research,66(1-2), 1-19. DOI: 10.1016/S01698095(02)00174-6.

Oh SN, Sohn BJ, Chung HS.Park KJ, Park SS. 2003. Atmospheric aerosol optical properties in the Korean peninsula. In Proceedings of the Korea Air 
Pollution Research Association Conference (pp. 423-423). Korean Society for Atmospheric Environment.

Miller RL, Tegen I, Perlwitz JP. 2004. Surface radiative forcing by soil dust aerosols and the hydrologic cycle. Journal of Geophysical Research: Atmospheres, 109(D4),. DOI: 10.1029/2003JD004085. accelerant for an increasingly arid climate in North China. Journal of Arid Environments, 72(8), 1476-1489. DOI: 10.1016/j.jaridenv.2008.02.017

Huneeus N, Schulz M, Balkanski Y, Griesfeller J. 2011. Global dust model

Han Y, Dai X, Fang X, Chen Y, Kang F. 2008. Dust aerosols: a possible intercomparison in Aerocom phase i. Atmospheric Chemistry and Physics, 10(10), 7781-7816. DOI: 10.5194/acp-11-7781-2011.

Jemmett-Smith BC, Marsham JH, Knippertz P, Gilkeson CA. 2015. Quantifying global dust devil occurrence from meteorological analyses. Geophysical Research Letters, 42(4), 1275-1282. DOI: 10.1002/2015GL063078.

Huang J, Wang T, Wang W, Li Z, Yan H. 2014. Climate effects of dust aerosols over east Asian arid and semiarid regions: climate effects of east Asian dust. Journal of Geophysical Research, Atmospheres,119(19). DOI: 10.1002/2014JD021796.

Othman N, Matjafri MZ, Lim HS, Abdullah K. 2010. Climate affected by dust aerosol over arid region of makkah, Saudi arabia. Proceedings of the 
SPIE, 7859(4), 239-239. DOI: 10.1117/12.869507.

545

546

547

548

549

550

551

552

553

554

555

556

557

558

559

560

561

562

563

564

Kang J, Yoon S, Shao Y, Kim SW. 2011. Comparison of vertical dust flux by implementing three dust emission schemes in wrf/chem. Journal of Geophysical Research, 116(D9), (D9). DOI:10.1029/2010JD014649.

Falkowski PG, Barber RT, Smetacek V. 1998. Biogeochemical controls and feedbacks on ocean primary production. Science, 281(5374), 200-207. DOI:10.1126/science.281.5374.200.

Goudie AS. 2014. Desert dust and human health disorders. Environment International, 63(.), 101-113. DOI: 10.1016/j.envint.2013.10.011.

Xin J, Zhang W, Yuan J, Liu L. 2003. Study on attenuation of direct solar flux by sand-dust aerosol in Tengger desert. Journal of Desert Research, 23(3), 311-315. DOI: 10.1007/s11769-003-0037-0

Bangert M, Nenes A, Vogel B, Vogel H, Barahona H, Karydis VA, Kumar P, Kottmeier C, Blahak U. 2012. Saharan dust event impacts on cloud formation and radiation over western Europe. Atmospheric Chemistry and Physics, 12(9), 4045-4063. DOI: 10.5194/acp-12-4045-2012.

Slingo A, Ackerman TP, Allan RP, Kassianov EI, Mcfarlane SA, Robinson GJ, Barnard JC, Miller MA, Harries JE, Russell JE. 2006. Observations of the impact of a major Saharan dust storm on the atmospheric radiation balance. Geophysical Research Letters, 33(24), 409-421. DOI: 10.1029/2006GL027869. 
565

566

567

568

569

570

571

572

573

574

575

576

577

578

579

580

581

582

583

584

585

Davidi A, Kostinski AB, Koren I, Lehahn Y. 2012. Observational bounds on atmospheric heating by aerosol absorption: radiative signature of transatlantic dust. Geophysical Research Letters, 39(4). DOI: 10.1029/2011g1050358.

Sokolik I, Golitsyn G. 1993. Investigation of optical and radiative properties of atmospheric dust aerosols. Atmospheric Environment. Part A. General Topics, 27(16)(16), 2509-2517. DOI: 10.1016/0960-1686(93)90023-R.

Mani A, Chacko O. 1980. Attenuation of solar radiation in the atmosphere. Solar Energy, 24(4), 347-349. DOI: 10.1016/0038-092X(80)90296-0.

Hatzianastassiou N, Papadimas CD, Gkikas A, Matsoukas C, Sayer AM, Hsu NC, Vardavas I. 2014. Aerosol radiative effects over global arid and semiarid regions based on MODIS deep blue satellite observations. Egu General Assembly Conference. EGU General Assembly Conference. Abstracts.

Zijiang Z, Xiwen W. 2002. Analysis of the severe group dust storms in eastern part of northwest china. Journal of Geographical Sciences, 12(3), 357-362. DOI: $10.1007 / \mathrm{BF} 02837557$.

Meng C, Li H. 2019. Solar radiation partitioning and surface albedo parameterization in the hinterland of Taklimakan Desert. Advances in Meteorology, 2019, 1-8. DOI: 10.1155/2019/9098576.

Fei Y, Xia X, Che H. 2014. Dust aerosol drives upward trend of surface solar radiation during 1980-2009 in the Taklimakan Desert. Atmospheric Science Letters, 15(4), 282-287. 
586 Huang G, Liu Q, Wang Y, He Q, Liu P. 2020. The accuracy improvement of

587

588

589

590

591

592

593

594

595

596

597

598

599

600

601

602

603

604

605

606 clear-sky surface shortwave radiation derived from ceres ssf dataset with a simulation analysis. Science of the Total Environment, 749, 141671.

Jin L, He Q, Jiang H, Xiao J, Zhao J. Zhou S, Zhao J. 2011. Unmanned aerial vehicle observations of the vertical distribution of particulate matter in the surface layer of the Taklimakan desert in China. Atmosphere, 11(9), 980-980.

Ma M, Yang X, He Q, Zhou C, Yang F. 2020. Characteristics of dust devil and its dust emission in northern margin of the Taklimakan Desert. Aeolian Research, 44(4).

William D, Collins P, Rasch B, Eaton B., Khattatov J. 2001. Zender Simulating aerosols using a chemical tran sport model with assimilation of satellite aerosolretrievals: methodology for INDOEX. Journal of Geophysical Research: Atmospheres, 106(D7), 7313-7336.

Tian L, Chang Z, Mu J, Cao N, Ma S. 2018. Influence of spring dust aerosol on radiation over the arid area in Hexi Corridor. Arid Land Geography, 41(05), 923-929.

Tegen I, Fung I. 1994. Modeling of mineral dust in the atmosphere: sources, transport, and optical thickness. Journal of Geophysical Research,99(D11), 22897-22914.

Sokolik I, Golitsyn G. 1993. Investigation of optical and radiative properties of atmospheric dust aerosols. Atmospheric Environment. Part A. General 
Topics, 27(16)(16), 2509-2517.

608

609

610

611

612

Sokolik IN, Toon OB. 1996. Direct radiative forcing by anthropogenic airborne mineral aerosols. Nature, 381(6584), 681-683. DOI: 10.1038/381681a0.

Wang X, Dong Z, Chen G. 2001. Characteristics of blown sand environment in middle Taklimakan desert. Journal of Desert Research, 21(01), 59-64.

Yang X, Li H, He Q. 2012. Blown sand activities in spring in the desert transitional zone of the Taklimakan Desert-a case in Xiaotang area. Journal of Desert Research, 32(4), 915-920.

Jin L, He Q, Li Z, Mamtimin A. 2014. Global solar radiation over different underlying surfaces in the Taklimakan desert. Journal of Desert Research, 34(02), 498-506.

Mamtimin A, Jin L, Li Z, Miao Q, He Q. 2014. Observational study of solar radiation on Taklimakan desert hinterland from 2007 to 2011. Progressus Inquisitiones De Mutatione Climatis, 10(2), 87-94.

Yang Y, Fan Y, Mamtimin A, Yang X, Huo W, Zhou C, He Q, Shuai C. 2018. Comparative analyses on surface radiation characteristic in Tazhong of the Taklamakan Desert and Guaizihu Lake of the Badain Jaran Desert. Journal of Desert Research, 38(05), 1068-1077.

Gao J, Wang Y, Hajigul S, Mamtimin A, Liu Y, Zhao X, Yang X, Huo W, Yang F, Zhou C. 2021. Characteristics of surface radiation budget in Gurbantunggut Desert. Journal of Desert Research, 41(01), 47-58. 
628 Zhang Z, Zhang H, Jin H, Ma X, Liu Z. 2015. Characteristics of scattered 629 radiation change in Golmud. Meteorological Science and Technology, 43(02), $630 \quad 270-275$.

631 Zhang H, Zhang H, Wang Q. 2013. Variation characteristics of total radiation 632 and reflected radiation in Golmud area. Journal of Nanjing University of 633 Information Engineering. (Natural science edition), 5(05), 449-454.

634 Qian L, Liu M, Yang Y, Lan X. 2011. Characteristics of change in solar radiation 635 and solar energy resources use over the eastern Hexi corridor. Resources $636 \quad$ Science, 33(05), 823-828.

637 Qiao Y, Gu S, Tang Y. 2008. Characteristics of diffuse radiation in Qinghai-Tibet $638 \quad$ Plateau. Acta Scientiarum Naturalium Universitatis Nankaiensis, 41(03).

639 Qiu H. 1996. Analysis of radiation climate characteristics and radiation resources 640 in Heihe Region. Heilongjiang Meteorology, 13(02), 9-14 + 37 .

641

642 
Figure 1

Geographical location diagram of Xiaotang, Taklimakan Desert

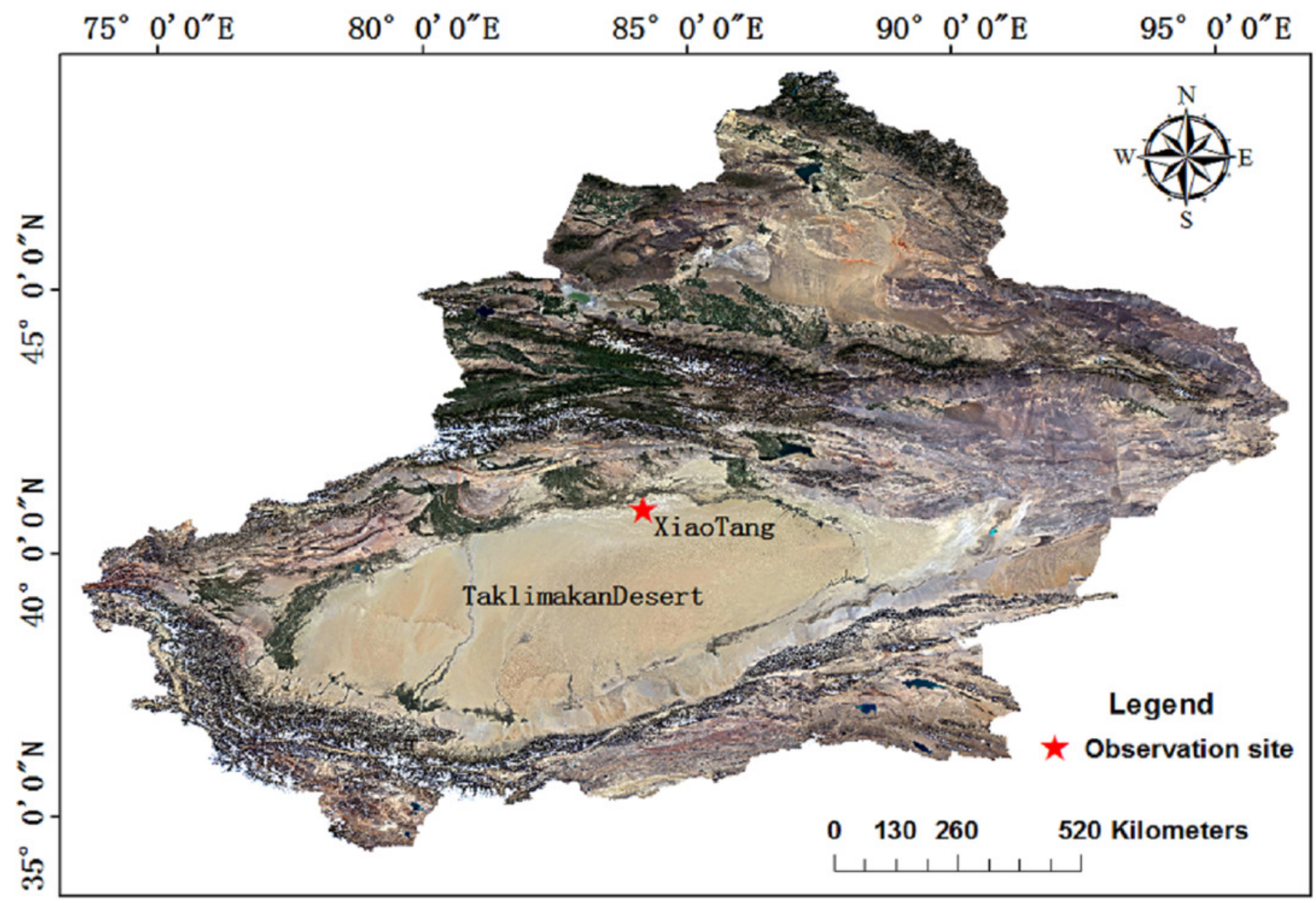


Figure 2

Monthly changes in wind speed, temperature, and humidity at the Xiaotang area in 2018

Figure

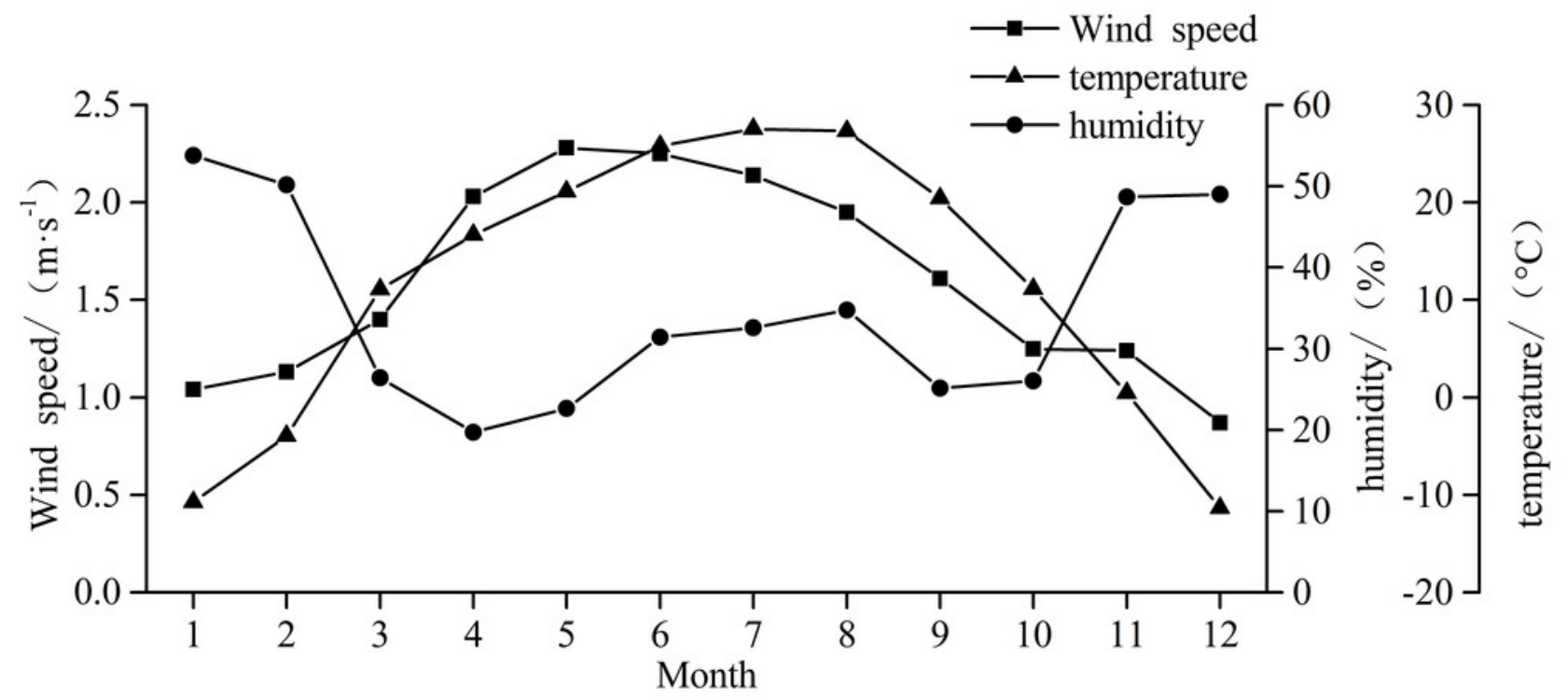


Figure 3

Annual variations in the total, direct, and scattered radiations at the Xiaotang area

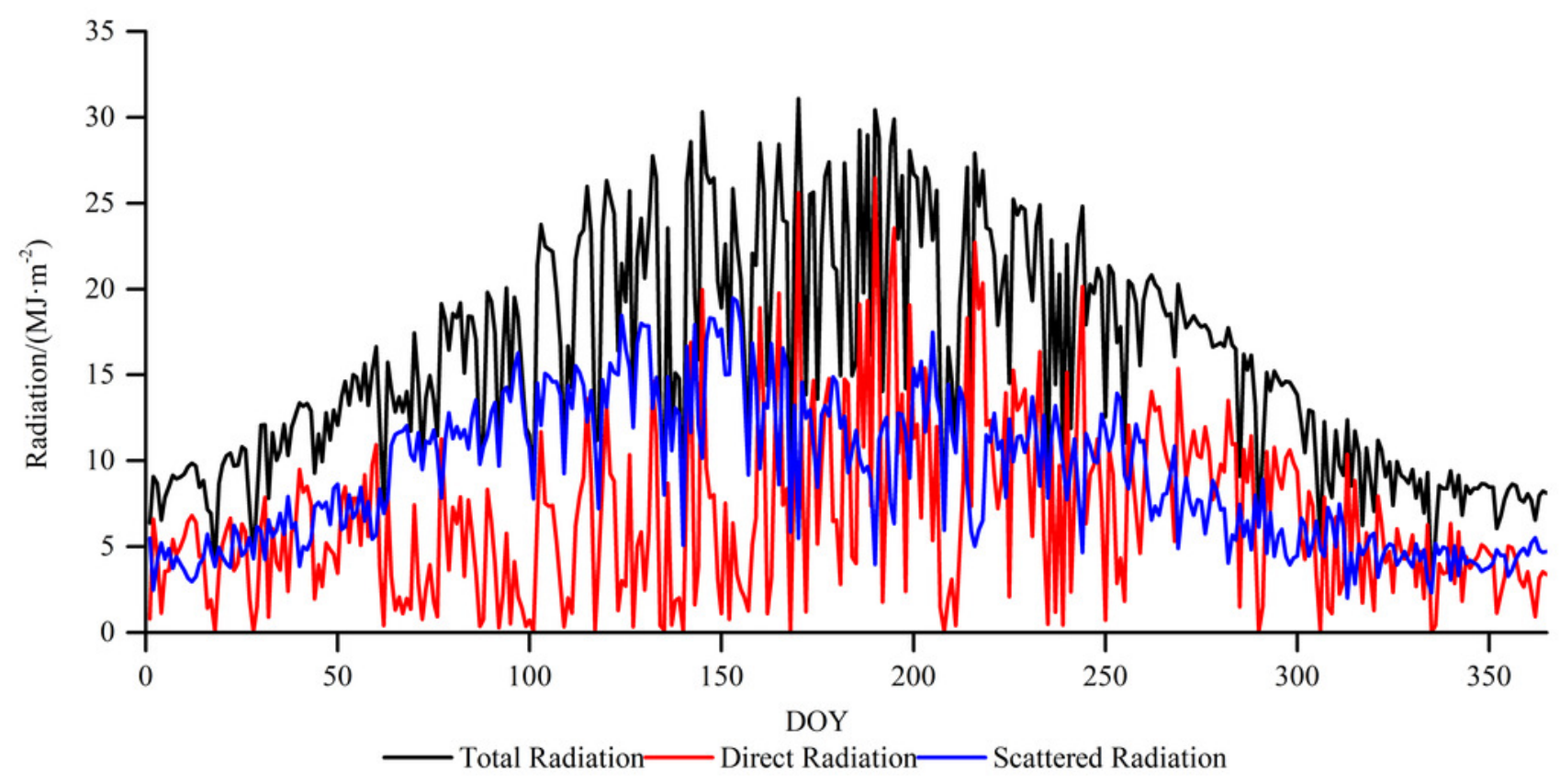


Figure 4

Monthly variation of total radiation, direct radiation, and scattered radiation at Xiaotang
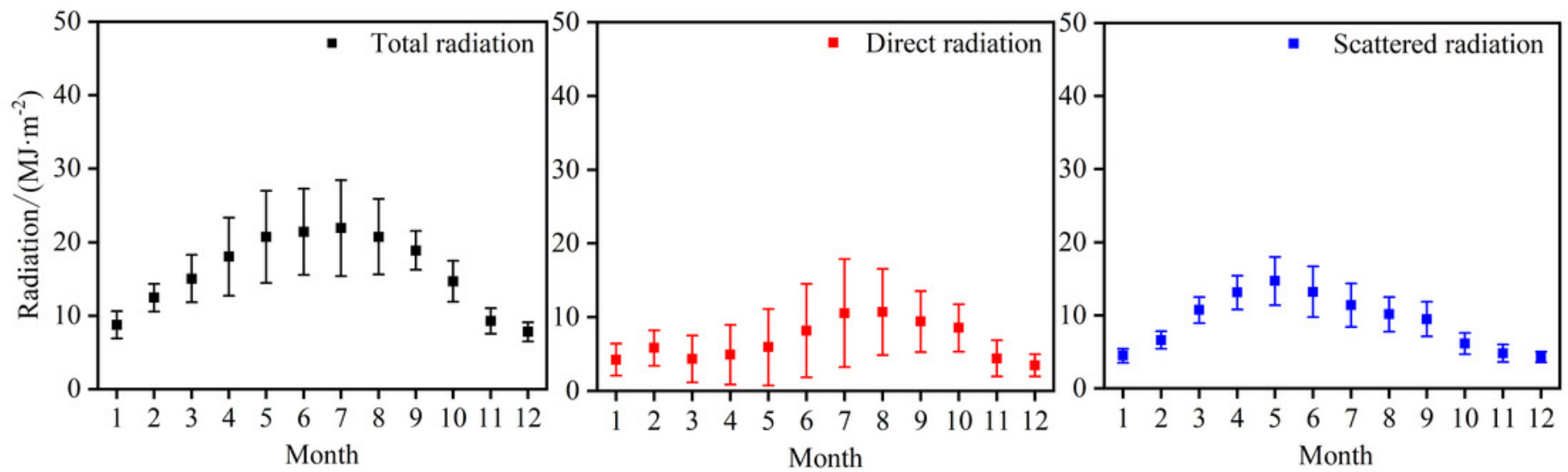
Figure 5

Daily variation of total radiation, direct radiation, and scattered radiation at Xiaotang in 2018

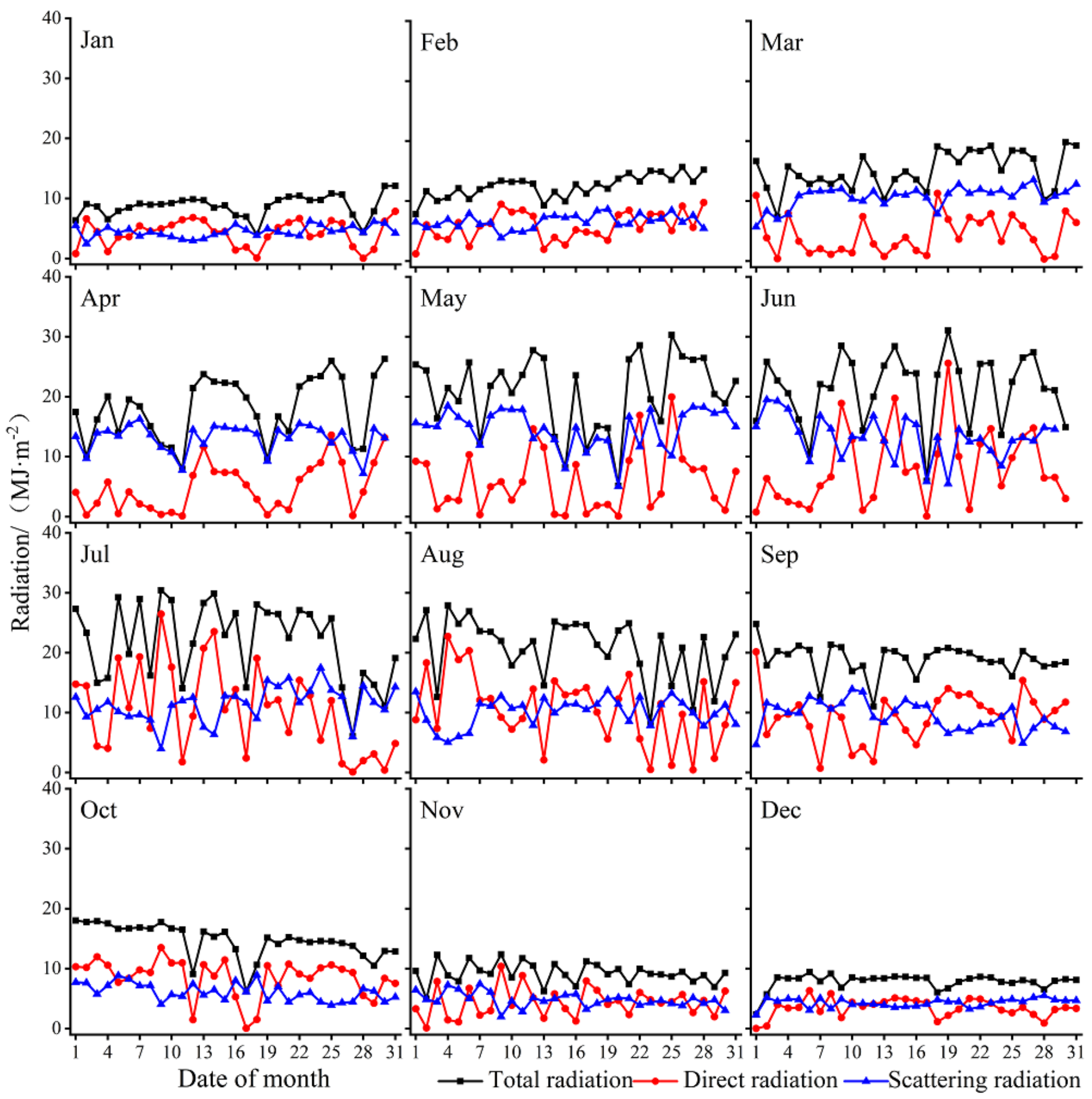


Figure 6

Relationship between total radiation and solar height angle on clear, floating-dust, blowing-sand, and sandstorm days at the Xiaotang area

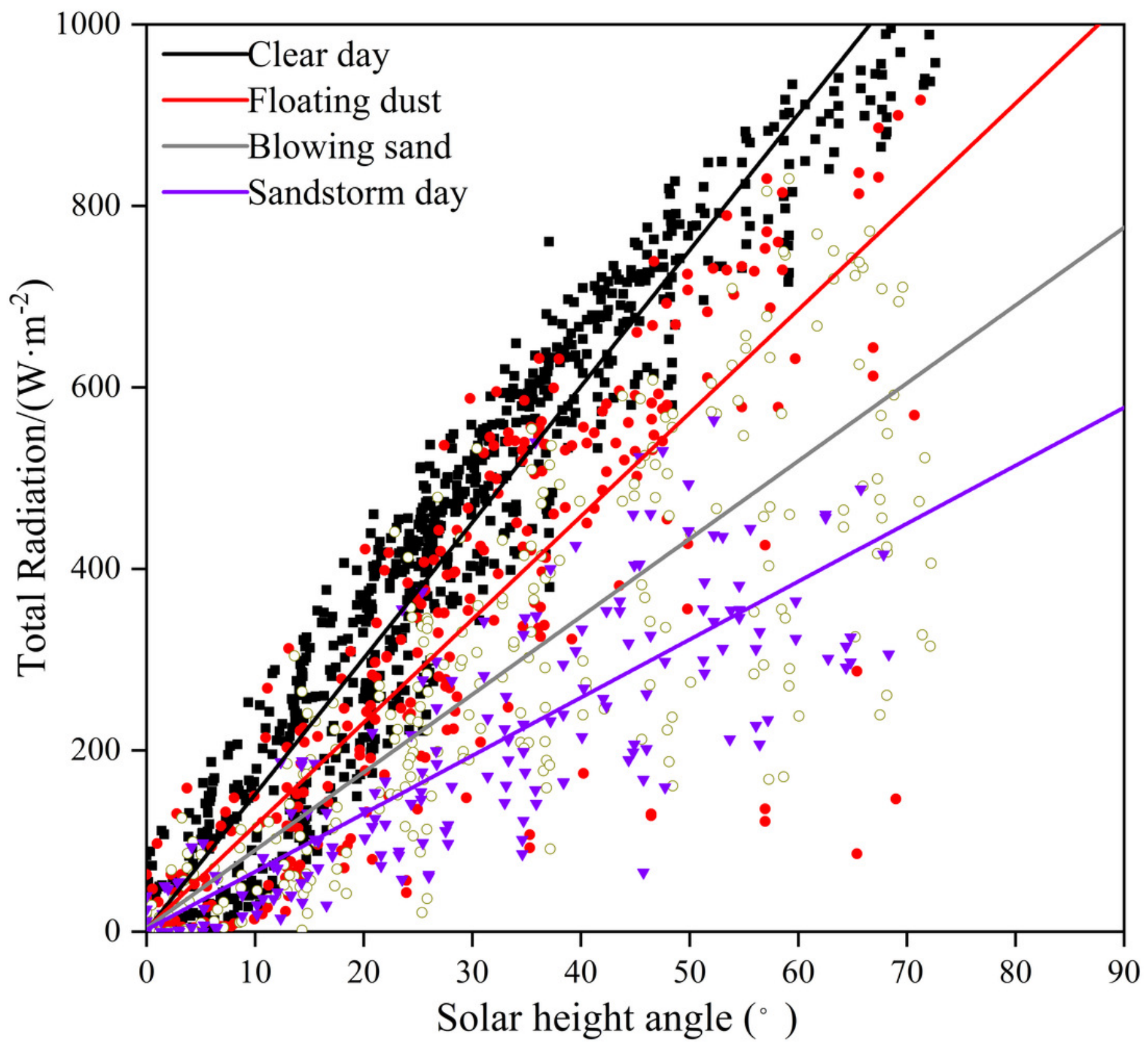


Figure 7

(A) Relationship of atmospheric transmittance and ratio of scattered radiation to total radiation $\left(R_{d} / R_{s}\right)$; (B) relationship of atmospheric transmittance and ratio of scattered radiation to astronomical radiation $\left([\mathrm{i}] \mathrm{R}_{\mathrm{d}} /\right.$
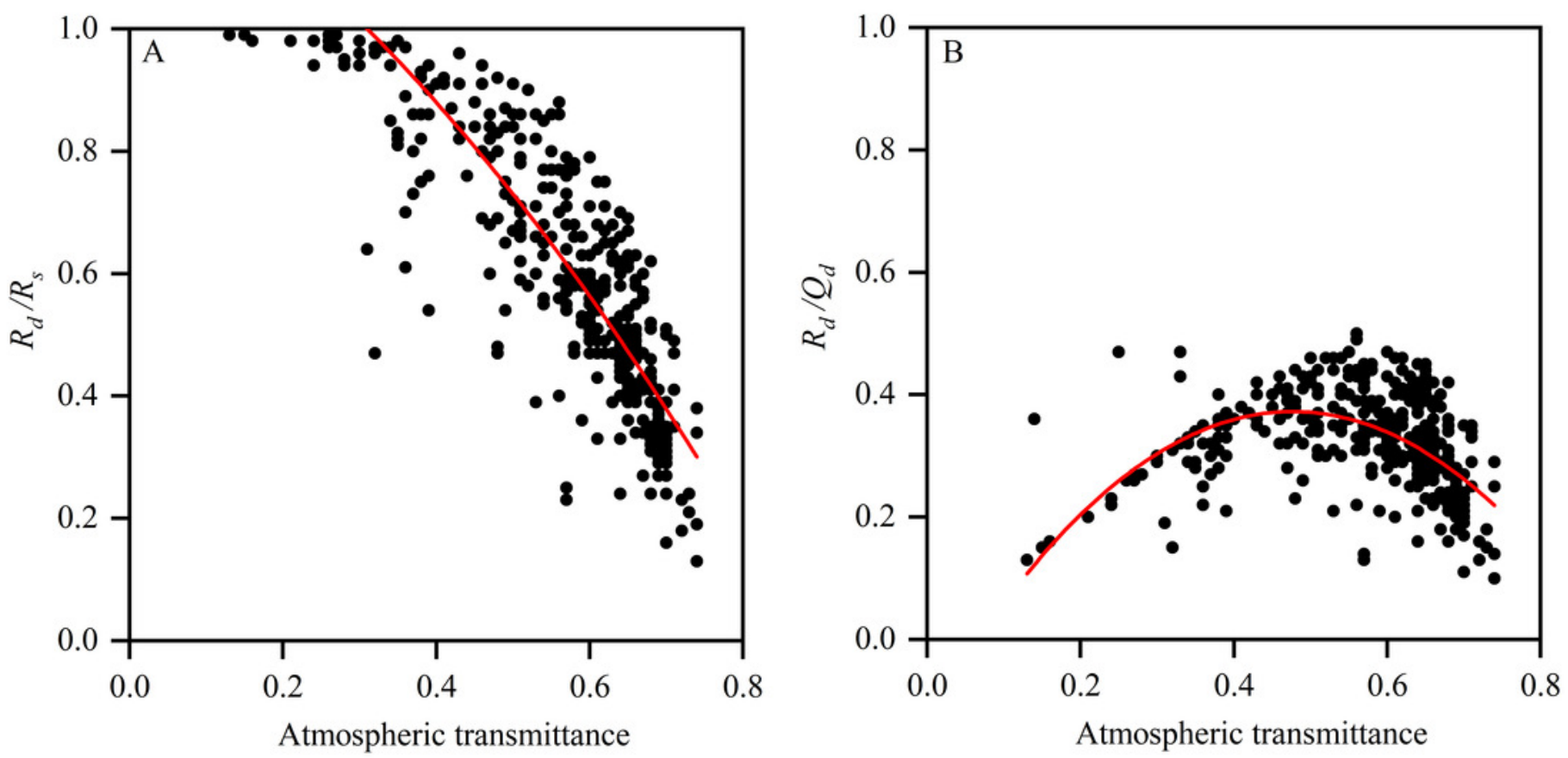
Figure 8

Diurnal variation of total radiation, direct radiation, and scattered radiation on clear, floating-dust, blowing-sand, and sandstorm days in spring (A) and summer (B) at Xiaotang
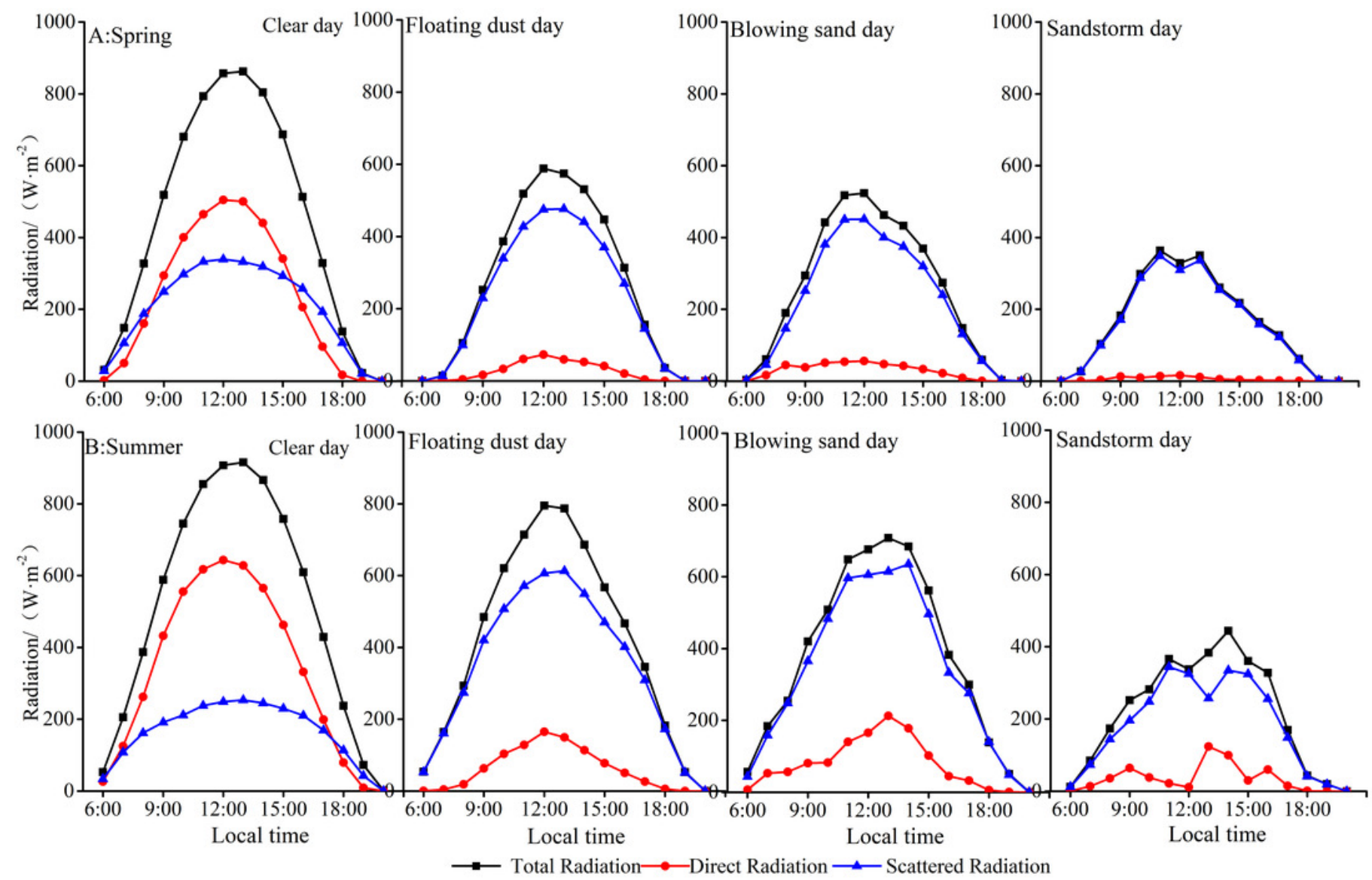
Figure 9

Figure 9 Probability distribution of total, direct, and scattered radiations values on clear, floating-dust, blowing-sand, and sandstorm days at the Xiaotang area
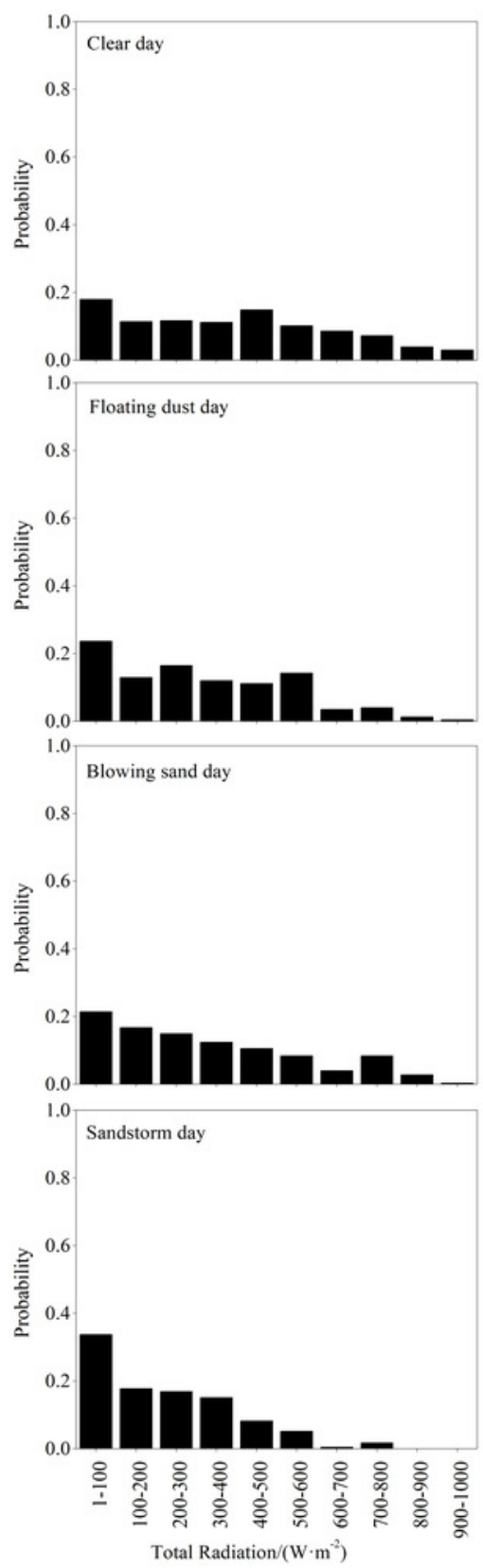
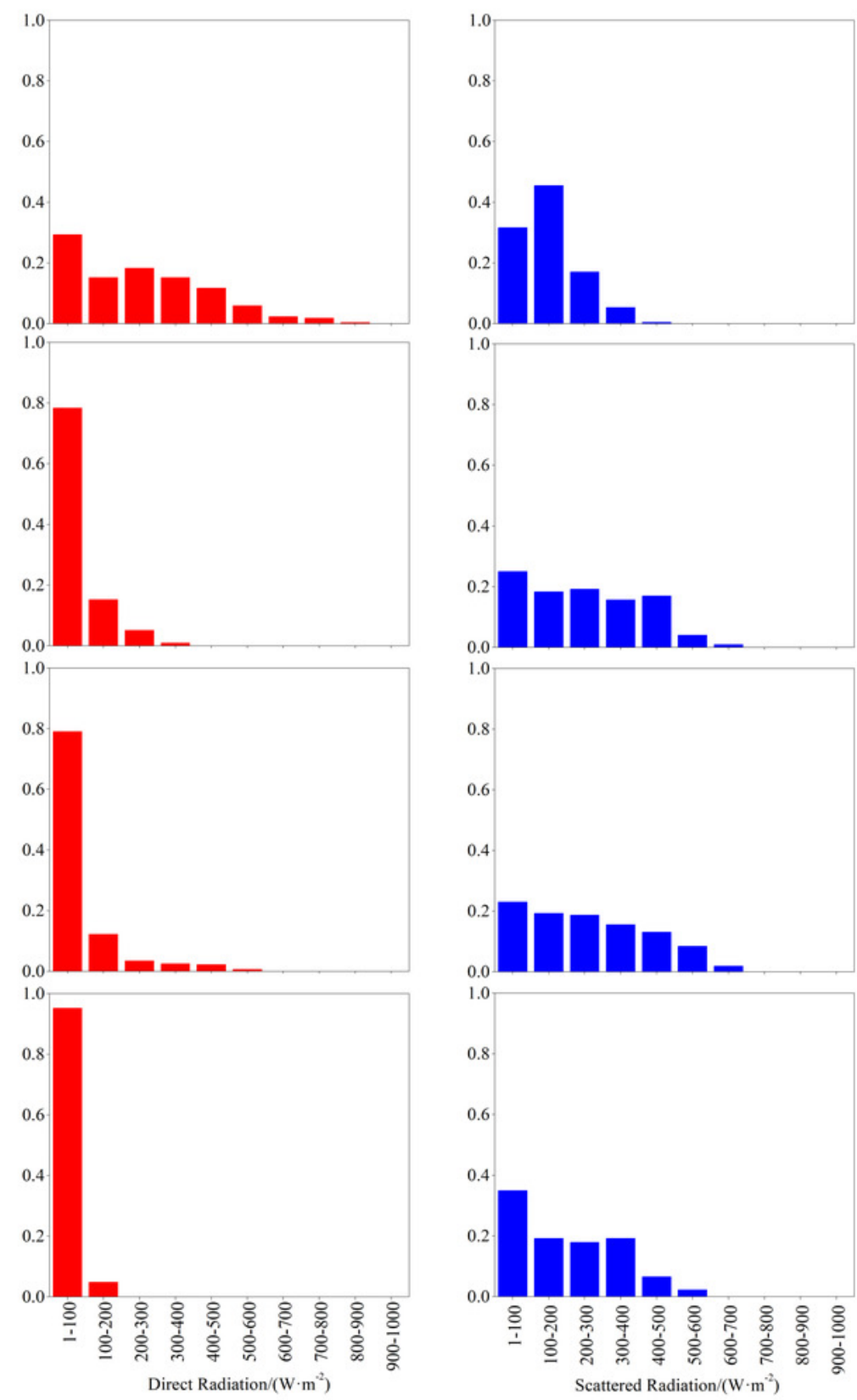
Figure 10

(A) Relationship between atmospheric transparency coefficient and the ratio of the direct radiation to the total radiation; $(B)$ relationship between atmospheric transparency coefficient and the ratio of the scattered radiation to the total radiation
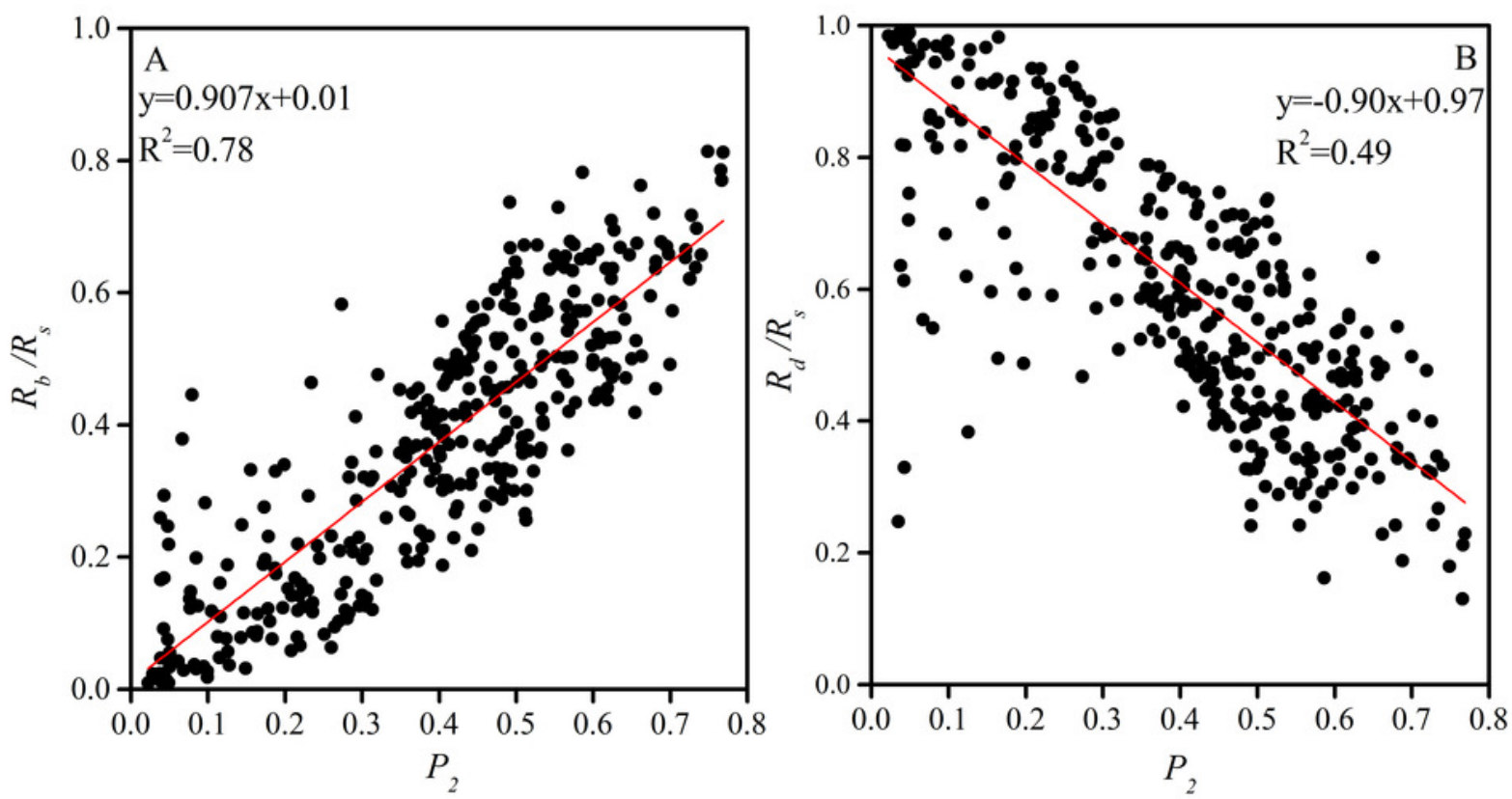
Figure 11

Monthly variation of direct radiation, scattered radiation, and AOD at Xiaotang in 2018

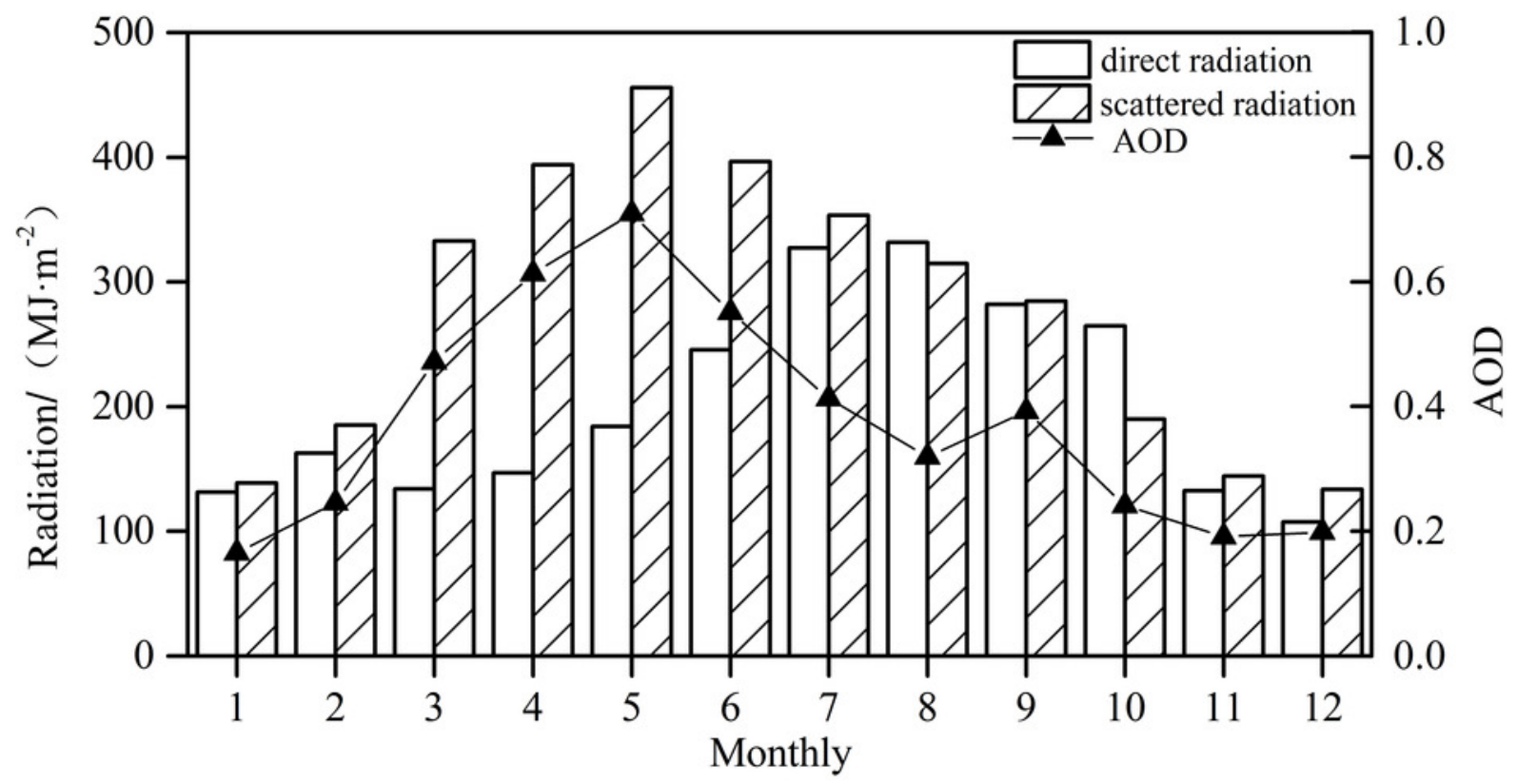


Table $\mathbf{1}$ (on next page)

Radiation detection instruments 
Table 1 Radiation detection instruments

\begin{tabular}{|c|c|c|c|c|}
\hline \multirow[t]{2}{*}{ Sensor } & \multirow[t]{2}{*}{ Model } & \multirow{2}{*}{$\begin{array}{l}\text { Installation } \\
\text { height(m) }\end{array}$} & \multirow{2}{*}{$\begin{array}{l}\text { Producing } \\
\text { country and } \\
\text { manufacturer }\end{array}$} & \multirow[t]{2}{*}{ Technical index } \\
\hline & & & & \\
\hline Total & SR20 & 1.55 & Netherlands & Spectral range: 300 \\
\hline \multirow[t]{5}{*}{ radiation } & & & Kipp\&Zonen & 2800nm; Sensitivity \\
\hline & & & & $15 \mu \mathrm{V} \cdot \mathrm{W}^{-1} ;$ Zero drift \\
\hline & & & & $<5 \mathrm{~W} \cdot \mathrm{W}^{-2} ;$ Operating \\
\hline & & & & temperature: $-40^{\circ} \mathrm{C}$ \\
\hline & & & & $80^{\circ} \mathrm{C}$ \\
\hline Direct & DR20 & 1.35 & Netherlands & Spectral range: 200 \\
\hline \multirow[t]{6}{*}{ radiation } & & & Kipp\&Zonen & 4000nm; Sensitivity \\
\hline & & & & $7-15 \mu \mathrm{V} \cdot \mathrm{W}^{-1}$ \\
\hline & & & & Temperature drift: $>$ \\
\hline & & & & $1 \mathrm{~W} \cdot \mathrm{W}^{-2} ; \quad$ Operating \\
\hline & & & & temperature: $-40^{\circ} \mathrm{C}$ \\
\hline & & & & $80^{\circ} \mathrm{C}$ \\
\hline Scattering & SR20 & 1.55 & Netherlands & Spectral range: 300 \\
\hline \multirow[t]{2}{*}{ radiation } & & & Kipp\&Zonen & 2800nm; Sensitivity \\
\hline & & & & $15 \mu \mathrm{V} \cdot \mathrm{W}^{-1} ;$ Zero drift \\
\hline
\end{tabular}




$<5 \mathrm{~W} \cdot \mathrm{W}^{-2}$; Operating
temperature: $-40^{\circ} \mathrm{C}-$
$80^{\circ} \mathrm{C}$

2

3 


\section{Table 2 (on next page)}

Monthly number of days of dust days occurrence at Xiaotang in 2018 
1 Table 2 Monthly number of days of dust days occurrence at Xiaotang in 2018

\begin{tabular}{cccccccc} 
Season & Month & $\begin{array}{c}\text { Floating } \\
\text { dust }\end{array}$ & Blowing & Sandstorm & Dust & Rainfall \\
& & sand & & devil & \\
\hline & March & 5 & 3 & 3 & 0 & 0 \\
Spring & April & 4 & 5 & 4 & 2 & 4 \\
& May & 7 & 3 & 8 & 7 & 5 \\
& June & 2 & 6 & 3 & 4 & 10 \\
& July & 0 & 8 & 1 & 4 & 16 \\
& August & 0 & 4 & 5 & 7 & 11 \\
\hline
\end{tabular}

2

3 